\title{
Literatura:
}

BUDAGOVA, L. N. (ed): Pax Latina \& Pax Orthodoxa: Slavističeskije issledovanija. Istorija, kul'tura, literatura. V čest' 8o-letija so dnja roždenija Aleksandra Vladimiroviča Lipatova. Moskva: Federal'noje gosudarstvennoje bjudžetnoje učreždenije nauki, Institut slavjanovedenija RAN, 2017. ISBN 978-5-7576-0406-0.

https://doi.org/10.5817/OS2018-3-12

\section{Pamät času si uchová meno a tvár svojho tvorcu}

V kultúrnom a literárnom živote, pri ich dynamike, členitosti, pestrosti aj naliehavosti sa vo vedomí spoločnosti darí predovšetkým tým tvorcom, ktorým sa nimi utvorenými nástrojmi dialógu s ňou z rozličných podnetov venuje výraznejšia, či až sústredená pozornost'. Média, kultúrne akcie, besedy, literárne rozhovory, výstupy tvorivej aktivity, záujem a ich vyhladávanie kultúrnou obcou spôsobujú, že sa o udalosti, jave či tvorivej osobnosti v istom čase a za istých okolností zvýrazňuje fakt, že má zmysel sledovat prejavenie sa a uplatnenie hodnoty v umení, dotvárat prospešnými rozhodnutiami dotyk jedinečnosti s výnimočnostou. Azda aj neželaným následkom, niet o také situácie núdze, sa do úzadia pozornosti, záujmu a zverejňovaných výpovedí o hodnote a šírení tradičnými aj novými prostriedkami kultúrneho a literárneho života dostanú ich dalšie a početné súčasti, lebo sa dostali, vdaka okolnostiam, do ich tieňa.

Panta rei, pohyb času a premeny v ňom naznačujú, že náručie dejín kultúry a literárnej histórie zostávajú otvorené času a jeho obsahom v umení a v literárnovednej tvorbe. Cúdenie podstatného od ostatného, ktorým sa čas obsiahnutý v pamäti spoločnosti a ňou podporovanej a oceňovanej kultúry, zvlášt v pôvodnej a prekladovej umeleckej spisby si osvojuje literárna veda svojimi súčastami, aby vytvorila hodnotovú a javovú zásobnicu pre syntézy, hoci aj tie, ktoré odborná a širšia verejnost̉ pozná vo forme dejín, kompendií, slovníkov či inak.

Dejiny kultúry a dejiny literatúry sa vyrovnávajú s obsahom, jedinečnost̉ou a podstatou literárneho života a literárneho procesu tak, že sa z času a jeho obsahov abstrahujú tie činy a riešenia, ktoré znamenajú - vdaka plynúcemu času, teda vývinu a ním iniciovaným procesom - oporné miesta a také istoty, z ktorých sa odvíjajú úvahy o zmysle, význame a jedinečnosti konkrétneho literárneho procesu, generácie, či konkrétneho genologického komponentu, literárnej estetiky, aby sa zmysluplne udržalo a účinne podporovalo spoločenskými prostriedkami a ich možnostami tvorivého zázemia osobností zapojených do jedinečnosti hodnotového povedomia (národného) kultúrneho spoločenstva a umenia. 
Femina, odkazujúc na publikáciu s rovnomenným názvom ${ }^{1}$, sústreduje sedemnást̉ slovenských autoriek ${ }^{2}$ v rokoch 1992 až 2008 do literárneho klubu, ten ich zblížil osobnými vztahmi, ale vytvoril aj dobré spoločenské a kultúrne podmienky na to, aby svojou pôvodnou a prekladovou tvorbou, širšie koncipovanom aktivitou a utváranou aj reprezentujúcou kultúrnou hodnotou v aktívnom literárnom a vydavatel'skom živote reagovali, podla zostavovateliek, na prežívajúcu „trhlinu“ nerešpektujúcu hodnotu aj rolu ich tvorby ako autentický vklad do kultúrneho dedičstva národnej osvety už aj tým, či práve preto, že „genéza predsudkov a zlahčovania tvorby ženských autoriek má svoje korene ovela hlbšie“"3.

Publikácia Femina má javovú zvláštnost', spravidla sa kolektívnymi prácami ich tvorcovia sústredujú na jednostranné predstavenie svojho spoločenstva. Femina naopak, necháva na dobovej literárnej kritike venovanej tvorbe autoriek klubu prehovorit’ o mieste, význame, vklade a príčine, prečo generačne rozvrstvené, žánrovo odlíšené, svojím profesijným a spoločenským postom vytažené a kritickou rezonanciou rozvrstvené prozaičky, poetiky, prekladatelky zovreli do literárneho klubu, v ktorom bez manifestov či d’alších zvyčajných gest uplatnili v literárnej výpovedi svoju empatiu voči životu, skúsenost', filozofovanie, zvažovanie o rodine aj o sebe, teda prečo a o čom má pre ne opodstatnenie i týmto spôsobom vypovedat a zdôverovat sa čitatelovi o svojom (aj jeho) životnom poslaní.

Femina v publikácii, tak sa rozhodli jej zostavovatelky, postupne vysvetluje Prečo vznikla Femina, prečo vznikla táto publikácia, zachytáva prostredníctvom sumujúceho biobibliografického prierezu sedemnásṫ Osobných a literárnych profilov a osemnást personalizovaných Rozhovorov. Pri autorských heslách zostavovatelky publikácie Femina upozornili na to, že si nenárokujú naplnenie precíznej normy spracúvajúcej informácie o tvorbe autoriek, ale ako protiváhu za túto neúplnost̉ ponúkajú kultivované, osobnostne zvýraznené a myslením o živote, svete, sebe a o umení dialógy/rozhovory s členkami klubu Femina.

Literárny klub Femina sa v publikácii autorsky predstavuje a tým oslovuje aj literárnu históriu, Marína Čeretková-Gállová, Viera Handzová-Miháliková, Karin Lászlová a Libuša Mináčová sú s ňou nadalej v kontakte, prostredníctvom výňatkov zo zverejnených kritických či kultúrnospoločenských výpovedí o tvorbe členiek

1 PŘÍHODOVÁ, D., FARKAŠOVÁ, E.: Femina. Klub slovenských prozaičiek v literatúre a kultúre. Profily a rozhovory. Martin: Matica slovenská, 2009.

2 Mária Bátorová, Marína Čeretková-Gállová, Helena Dvořáková-Jancurová, Etela Farkašová, Eleonóra Gašparová, Marianna Grznárová, L’uba Hajková, Viera Handzová-Miháliková, Karin Lászlová, Terézia Michalová, Libuša Mináčová, Daniela Př́ihodová, Paula Sabolová, Jana Šimulčíková, Viera Švenková, Anita Tešovičová, Milka Zimková.

3 PŘÍHODOVÁ, D., FARKAŠOVÁ, E.: Femina. Klub slovenských prozaičiek v literatúre a kultúre. Profily a rozhovory. Martin: Matica slovenská, 2009, s. 7. 
klubu. Do publikácie včlenené torzá reprodukujúce porozumenie aj hodnotenie spájajú jednotlivé členky Feminy predovšetkým s recenzistikou Etely Farkašovej, Jany Šimulčíkovej a Márie Bátorovej. Širší a početnejší záber vyňatý z literárnokritických reflexií sprevádza prozaickú tvorbu Etely Farkašovej, Viery Švenkovej a Milky Zimkovej.

Zverejneniu publikácie s dejinami literárneho klubu Femina predchádzajú antológie poviedok Espresso Eva (1994), Planéta zrýchleného pohybu (1996) a za autorskej účasti rakúskych spisovateliek Zbližovanie (1996) a s nórskymi autorkami sa stretli v antológii Ženy a fjordy (2001). O šírenie tvorivého zázemia Feminy sa pričinili dvojjazyčné a preložené antológie spomedzi ich krátkych žánrov. L’udskú, emotívnu a mravnú empatiu voči tvorbe a životu Maše Halamovej a Margity Figuliovej členky klubu Femina vyjadrili im dedikovanými literárnymi večermi, pričinili sa aj o literárne iniciované výstavy, početné literárne a kritické besedy o svojej tvorbe a vyvrcholením aktivity klubu Femina sú Cena Feminy a Cena porozumenia.

Literárny klub Femina, organizačne včlenený do Spolku slovenských spisovatelov, uzavrel svoj klubový život v roku 2008, ale vdaka empatickej publikácii premyslene vyplnil poznanie o literárnej spisbe tvorenej poučenými spisovatelkami s tematickými a nazeracími stratégiami uplatnenými predovšetkým v osobnej tvorivej dielni aj pri odbornom či poučenom precizovaní kontaktov umenia a spisby so spoločenskými blížencami literárnej vedy. Vzácnost̉ou publikácie pre čitatela dnes i v budúcnosti zostáva fotodokumentácia, na ktorú je publikácia žičlivá.

Publikácia venovaná literárnemu klubu Femina v literárnom živote a vo vývine slovenskej literatúry posledných desatročí zastupuje výpoved’ o parciálnom a dostredivo utvorenom spoločenstve, obrazne $\mathrm{v}$ dejinách kultúry a literatúry, ide o dobové pars pro toto aktívneho literárneho života. Partnerská, premyslene literárnohistoricky koncipovaná publikácia Pohyb k nehybnosti ${ }^{4}$ má rekonštrukčnú ambíciu podporenú obnovením vývinových pohybov, úsporným výkladom, užitočným a potrebným spresnením a vymedzením podstatných detailov, ocenit treba zvýraznenú prepojenost̉ mimoliterárnych a literárnych, politických, ekonomických a kultúrnych činitelov napojených na kontinuitu a kauzalitu verifikovatelných spoločenských pohybov od konca pätdesiatych po ranne devätdesiate roky minulého storočia. Literárnohistorickou metodikou sprevádzaný kompozičný zámer tvorcov publikácie vytažil zo zaznamenaného pohybu na fotodokumentoch prepojenost̉ a zosúladenie časovej, organizačnej, personálnej a javovej „reality“ pripomenutých desatročí, preto „súčastou publikácie sú citáty z dobovej kultúrnej a dennej tlače, ako aj z „druhého brehu“ - zo svedeckej biograficko-memoárovej knihy Hany

4 PETRÍK, V., BARBORÍK, V.: Pohyb k nehybnosti. Literárny život od začiatku 6o. do konca 7o. rokov objektívom Antona Šmotláka. Bratislava: Literárne informačné centrum, 2018. 
Ponickej Lukavické zápisky. Funkcia citátov je dvojaká - informatívna a evokačná"5.

Historickým a spoločenským východiskom na rekonštrukciu zložitých spoločenských a personálnych pohybov v šesṫdesiatych rokoch a v sedemdesiatych rokoch sa stala literárnohistoricky, predovšetkým kauzálne a výkladovo koncipovaná čast̉ K problematike slovenského literárneho života po roku 1948, v ktorej sa zdôrazňuje a zvýrazňuje koncept dosahu a predovšetkým presahu ekonomického, politického, inštitucionálneho, personálneho riadenia štátu, účinkovanie moci, jej (do)presahy do kultúrneho, literárneho aj osobného tvorivého života slovenských literátov, literárneho života a literárnej vedy.

Do blokov, ilustračne sprevádzaných fotografiami získanými z akcií Kultúrneho života, Slovenského spisovatela, rokovaní spisovatel'ských zjazdov, sú rozložené roky Šest́desiate v týchto tematických konceptoch: Roky šest'desiate, Konferencie a zjazdy, Redakcie, Návštevy, Ceny, výlety a kolektívny duch, Tváre. Po tomto desatročí, informáciami, faktograficky a verifikovatelne rozširujúcom dostupné učebnicové informácie, nasleduje další, nastupujúcim desatročím zovretý blok pomenovaný Sedemdesiate - normalizačný epilóg a samostatná čast̉ venovala autorovi fotografií Anton Šmotlák.

Grafická úprava publikácie naznačuje, že sa vydavatel prispôsobil vzácnym dobovým fotografiám. Príčinne prepájanie udalostí v jednom aj v po ňom nasledujúcom svojimi ambíciami tak odlišnom - desatročí vôkol časopisov, vydavatelstiev, inštitúcií, organizácií, udalostí aj jednotlivcov, pričinením sa „priamočiareho“ výkladu, metódy a spôsobu, ktorými sa literárnohistorickej náučnej a vzdelávacej rovine publikácie vyrovnávajú jej tvorcovia s reáliami, zostane ich zámer cenným, ale predovšetkým zrozumitelným, verifikovatelným a nanajvýš užitočným návratom do nedávnej minulosti. Napokon odstup od historicko-spoločenskej pamäti a sústredenie sa na pohyby a činy v literárnom, kultúrnom a vednom živote obidvoch desatročí potvrdzujú, že bez dôkladného poznania, poučeného porozumenia tomu, čo sa dialo, kto rozhýbava koleso ludských dejín, ale aj akým spôsobom a výsledkom koleso ludských príbehov, zostali by v opare nepresností, parciality a reinterpretácií tak podstatné (ne)pohyby, na ktoré reagoval dobový a literárny život, ale nie iba on. Napokon čas prirodzene napreduje, priestor sa modifikuje, generácie utvárané ludským rodom sa menia aj vdaka tomu, čo o svojej minulosti vedia, ale ani vtedy by nemali pozabudnút na spoločnú pamät', do ktorej sú po jej tvorcoch uložené ich mená aj tváre.

Viera Žemberová

5 PETRÍK, V., BARBORÍK, V.: Pohyb k nehybnosti. Literárny život od začiatku 6o. do konca 7o. rokov objektívom Antona Šmotláka. Bratislava: Literárne informačné centrum, 2018, prebal publikácie. 


\section{Literatúra:}

PŘÍHODOVÁ, D., FARKAŠOVÁ, E.: Femina. Klub slovenských prozaičiek v literatúre a kultúre. Profily a rozhovory. Martin: Matica slovenská, 2009. ISBN 978-80-7090-936-2.

음 PETRÍK, V., BARBORÍK, V.: Pohyb k nehybnosti. Literárny život od začiatku 6o. do konca 7o. rokov objektívom Antona Šmotláka. Bratislava: Literárne informačné centrum, 2018. ISBN 978-8081191-09-1. 